Reprod. Nutr. Dévelop. 1980, 20 (4 A), 905-921.

\title{
The effects of pig follicular fluid upon the ultrastructure of rat granulosa cells in tissue culture
}

\author{
par Jacqueline BERNARD, H. MERCHANT-LARIOS ( $\left.{ }^{1}\right)$ \\ Instifuto de Investigaciones Biomédicas \\ Universidad Nacional Autónoma de México (UNAM) \\ Apartado Postal 70228, México 20 D. F., México.
}

\begin{abstract}
Summary. The ultrastructure of rat granulosa cells from preovulatory follicles has been investigated after incubation in control fetal calf serum (FCS) medium with or without LH $(1 \mu \mathrm{g} / \mathrm{ml})$, and in total or steroid-free pig follicular fluid (FF) medium. While the cells had a similar ultrastruciure after 1 day of incubation in these media, significant differences were defectable after 3 days. In FCS supplemented with LH, autolysis and phagocytotic activity remained elevated, and cells did not develop any of the typical ultrastructural features of steroid-secreting cells. In contrast, total FF induced complete differentiation of mitochondrial cristae from the lamelliform to the villiform type. Steroid-free FF induced the same array of effects as total FF, except that mitochondrial differentiation was not complete. These observations together with those of previous studies, in which progesterone secretion was measured in cells incubated in the same media, suggested that the development of the capacity to secrete progesterone in rat luteal cells could be directly related only to mitochondrial differentiation.
\end{abstract}

\section{Introduction.}

The effects of pig follicular fluid (FF) upon the morphology of cultured rat granulosa cells have been studied under the light microscope (Bernard, 1975). This medium appears to repress differentiation, although it greatly enhances progesterone secretion compared to the control media due to the luteotrophic influence of estrogen present in FF. Bernard and Chrétien (1978) have shown dissimilarities in the surfaces of cells incubated in the different media with the scanning electron microscope. Recently, Ledwitz-Rigby et al. (1977), using light microscopic and biochemical techniques, have suggested that a luteinization inhibitor is present in steroid-free FF from small pig follicles.

The purpose of this study is to examine the influence of fetal calf serum (FCS) and total or steroid-free FF upon the ultrastructural differentiation of cultured rat granulosa cells, utilizing transmission electron microscopy.

(1) Please send correspondance and proofs to the second author at the above address. 


\section{Material and methods}

Fresh pig ovaries were obtained at a local slaughterhouse. FF was aspirated from follicles 2 to $10 \mathrm{~mm}$ in diameter, pooled, centrifuged, and stored at $-30^{\circ} \mathrm{C}$. Half of this fluid as well as fetal calf serum (Difco) were then treated with charcoal in order to remove the steroids, as previously described (Bernard, 1975). Radioimmunological assays of pooled pig FF showed that the untreated FF contained 140 to $200 \mathrm{ng} / \mathrm{ml}$ estradiol-17 (number of samples, $n=3$ ), 200 to $500 \mathrm{ng} / \mathrm{ml}$ progesterone $(\mathbf{n}=5$ ), $50 \mathrm{ng} / \mathrm{ml}$ androstenedione $(\mathrm{n}=1)$, and $20 \mathrm{ng} / \mathrm{ml}$ testosterone $(\mathrm{n}=1)$. After charcoal treatment, steroid concentrations fell to less than 1 p. 100 of the initial values (Castanier and Bernard, 1978, unpublished data).

Immature female Wistar rats (23-27 days old) were given a single subcutaneous injection of pregnant mare serum gonadotropins (PMSG, $30 \mathrm{IU}$ ) in the morning. These steroids are known to induce a preovulatory surge of endogenous $\mathrm{LH}$ in this strain 50-52 hrs later. The rats were sacrificed on the evening of the same day after the LH surge, and the granulosa cells were harvested from the preovulatory follicles as previously described (Bernard, 1975). The cells were transferred on plastic coverslips (Lux Scientific Corp.) to Leighton tubes containing the culture media $\left(3-5 \times 10^{5}\right.$ cells/tube) and incubated for 1 or 3 days at $37^{\circ} \mathrm{C}$ in an atmosphere of 5 p. $100 \mathrm{CO}_{2}$ in air.

The basal culture medium (BCM) was composed of 90 p. 100 TC 199 (Difco) and 10 p. 100 steroid-free fetal calf serum (FCS, Difco). The following culture media were used for cell incubation :

Control media.

1) 50 p. $100 \mathrm{BCM}$ and 50 p. 100 steroid-free FCS.

2) 50 p. 100 BCM and 50 p. 100 steroid-free FCS plus LH (ovine LH, $2.56 \times$ LH-NIH S1) at a final concentration of $1 \mu \mathrm{g} / \mathrm{ml}$.

FCS was used since its composition, particularly with regard to protein concentration, approximates that of pig FF (see review by Edwards, 1974).

Experimental media.

3) 50 p. 100 BCM and 50 p. 100 total FF.

4) 50 p. 100 BCM and 50 p. 100 steroid-free FF.

Penicillin and streptomycin were added to all media at final concentrations of $100 \mathrm{IU} / \mathrm{m}$ and $100 \mu \mathrm{g} / \mathrm{ml}$, respectively. The osmolarity of all media was about $295 \mathrm{mOsm}$.

FIG. 1. - Granulosa cells cultured for 24 hrs in control medium 1 in the presence of peroxidase. Phagocytosis of cell debris from necrotic areas can be seen (large arrow), but retention of peroxidase is poor (stars). Lipid droplets (L) and mitochondria with lamelliform cristae are visible. Note the presence of several trilaminar junctions (small arrows) $(\times 6200)$. Inset shows a higher magnification of the outlined trilaminar junction $(\times 24000)$. 


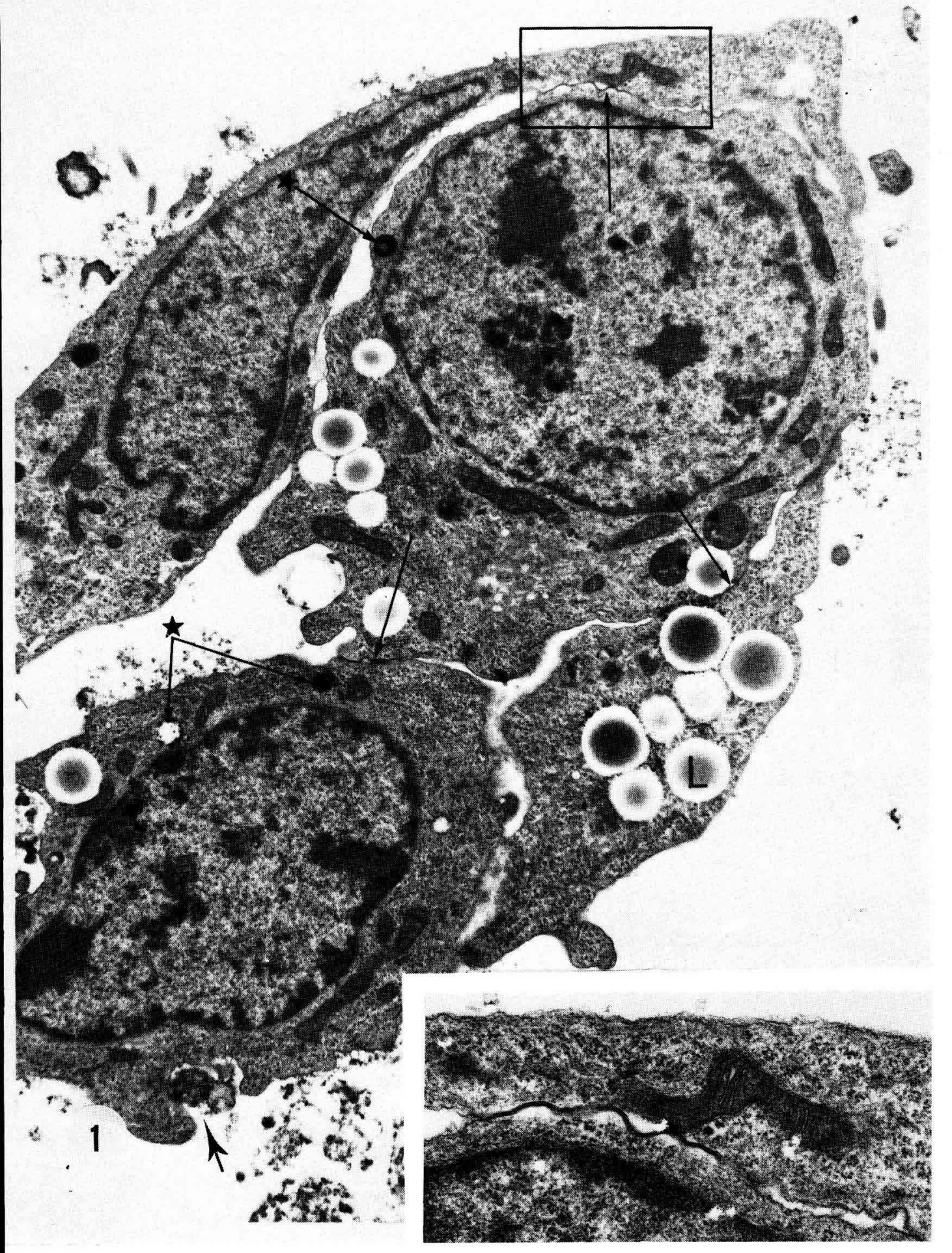


A series of three incubations (8-10 Leighton tubes/group) using each of the four media was carried out. Half the cells were fixed on day 1 and the rest on day 3. At the end of the incubation, cell cultures adhering to the coverslips were rinsed once with Hank's balanced salt solution and immediately immersed for 1-2 hrs in an icecold phosphate-buffered 2 p. 100 glutaraldehyde-paraformaldehyde fixative. The cells were then postfixed for 1-2 hrs in a « Zetterqvist» buffered 1 p. 100 osmium tetroxide solution (Zetterqvist, 1956). In some cases, ruthenium red $(0.5 \mu \mathrm{g} / \mathrm{ml}$ ) was added during postfixation in order to stain the mucopolysaccharide coat of the cell membrane. All cell cultures were dehydrated in a graded series of alcohols. The areas chosen for study under a light microscope were embedded in gelatin capsules filled with Epon 812. Thin sections were cut with a LKB microtome, stained with lead citrate for $2 \mathrm{~min}$ (Venable and Coggeshall, 1965), and examined under a Zeiss electron microscope.

Pinocytosis was studied using the peroxidase labeling method of Graham and Karnovsky (1966). Following incubation, horseradish peroxidase (Sigma, $1 \mathrm{mg} / \mathrm{ml}$ ) was added to the culture media for $30 \mathrm{~min}$. Cells were prefixed and rinsed three times in $0.01 \mathrm{M}$ PBS. The peroxidase was then visualized with 0.05 p. 100 3,3'-diaminobenzidine tetrahydrochloride (Sigma) in Tris buffer, $\mathrm{pH} 7.6$, for 5 min at room temperature, followed by the usual postfixation and dehydration. Peroxidase taken up into the cytoplasm of cells through pinocytosis appeared as electron-dense, irregular granules which may be fused with lysosomes.

\section{Results.}

The main morphological and developmental characteristics of granulosa cells incubated in different culture media are compiled in table 1.

Control media 1 and 2. - The mitochondria of cells incubated for 24 hrs in control medium 1 have platelike or lamelliform cristae. Microtubules are present as well as lysosome-like bodies and pleiomorphic heterogeneous granules of various sizes (figs. 1, 2). The cytoplasm contains a few dispersed cisternae of granular endoplasmic reticulum, abundant randomly-distributed free ribosomes, and a well-developed Golgi complex (fig. 2). Phagocytosis of cell debris from necrotic areas is often observed, but retention of peroxidase is relatively low (fig. 1). Ruthenium red strongly stains the cell coat and permits the visualization of some coated vesicles (fig. 2).

FIG. 2. - Cell incubated under the same conditions as in figure 1 with the cell surface stained by ruthenium red. Coated vesicles (arrows), mitochondria with platelike cristae, a well-developed Golgi complex, and abundant polyribosomes are visible $(\times 10000)$.

FIG. 3. - Parts of 3 granulosa cells incubated for 3 days in control medium 1 containing numerous plejomorphic mitochondria. Rough endoplasmic reticulum (RER), lipid droplets (L), and 2 trilaminar junctions (arrows) are present $(\times 15000)$. Inset shows a higher magnification of a trilaminar junction with a large number of microfilaments in the neighborhood $(\times 24000)$. 

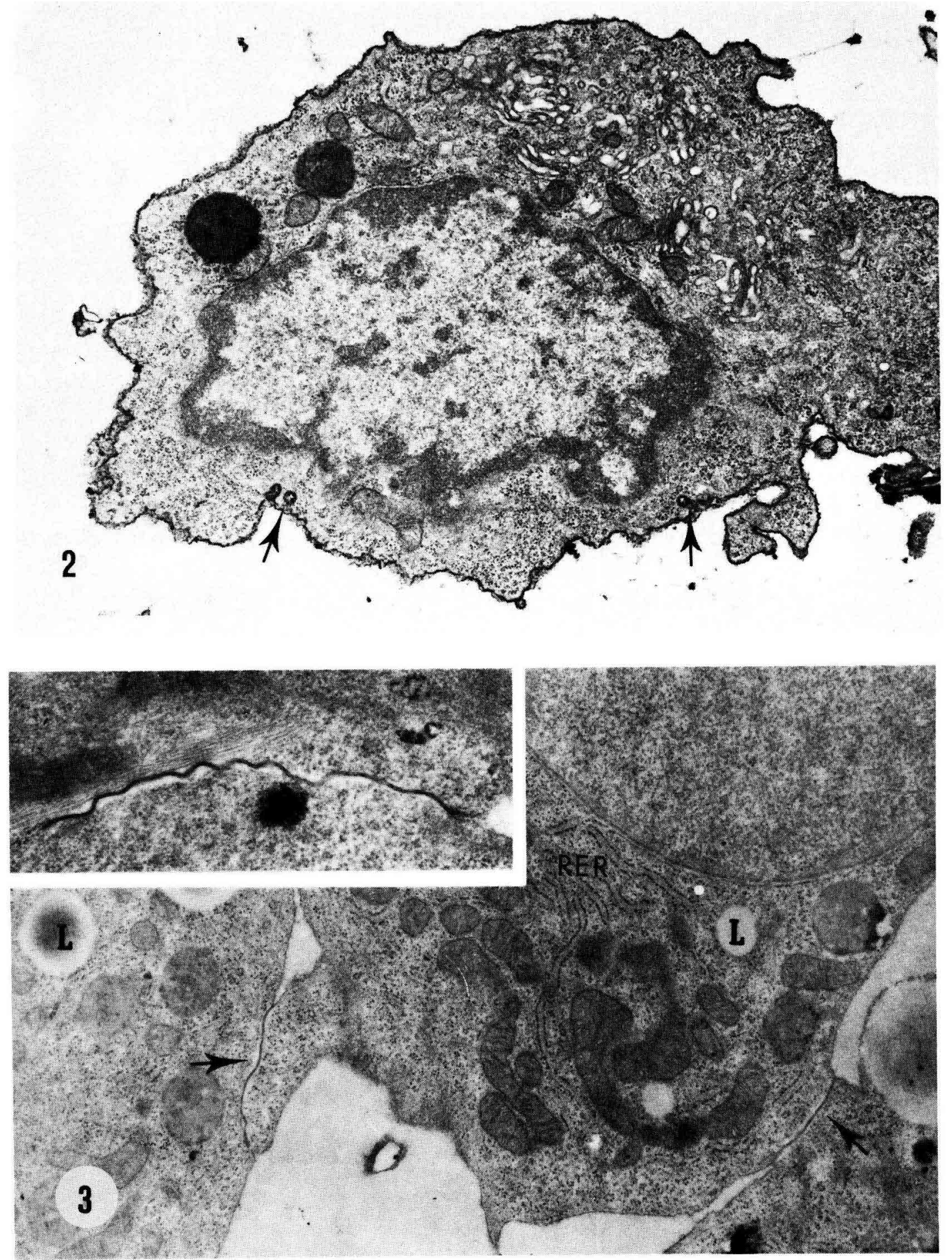


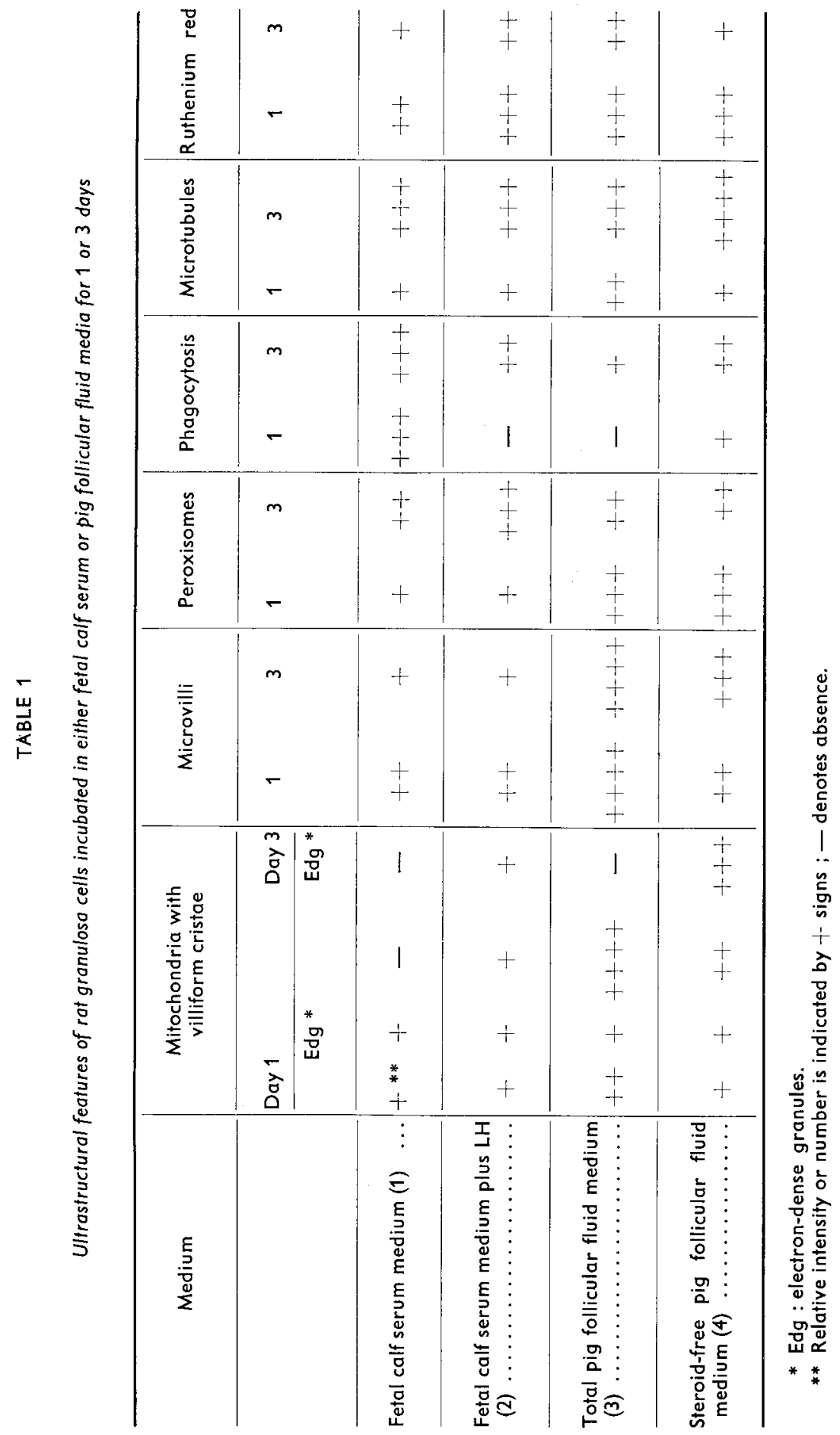



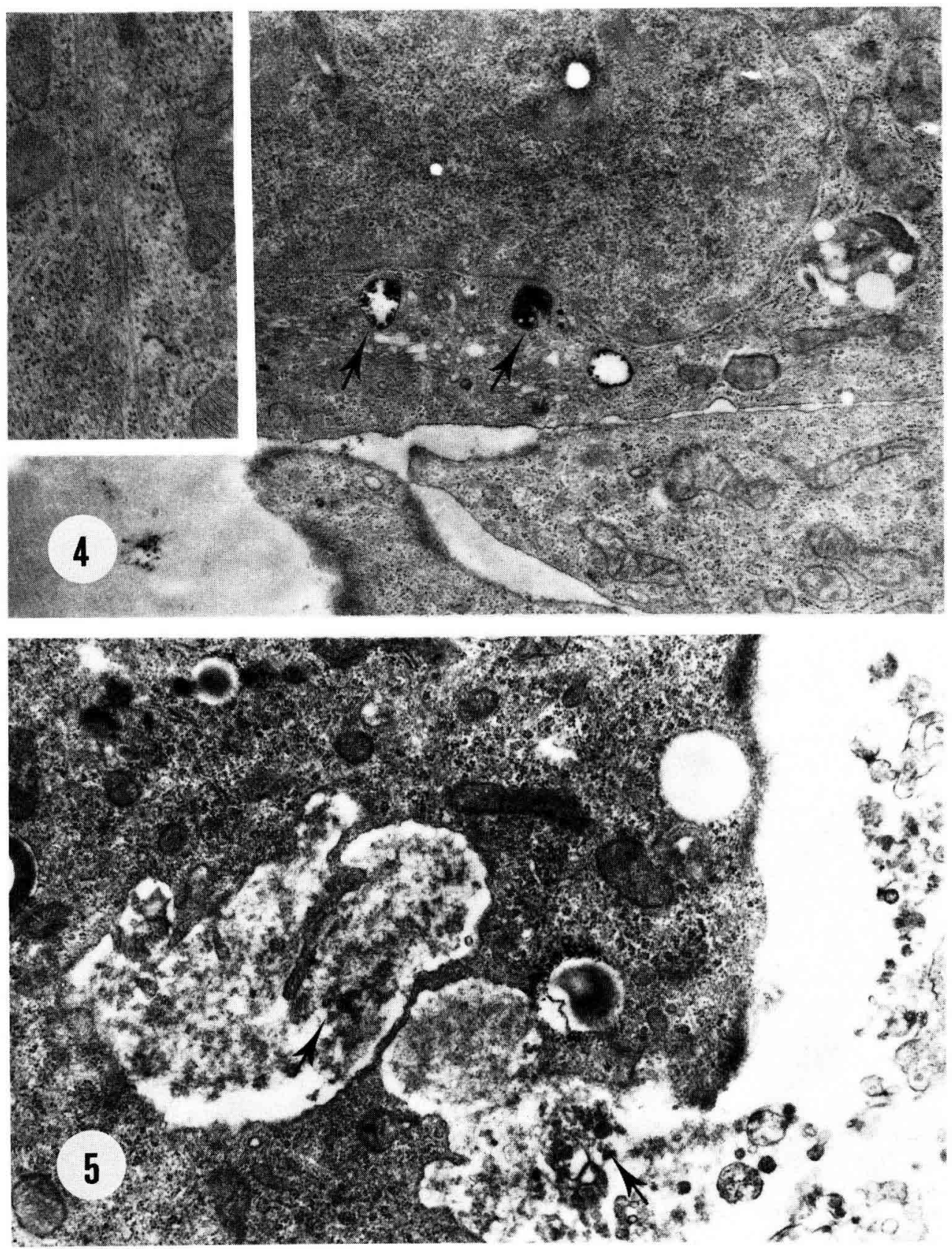

FIG. 4. - The uptake of peroxidase is increased after 3 days of incubation in control medium 1 (arrows) $(\times 14000)$. Inset demonstrates the great number of microtubules in the cytoplasm $(\times 24000)$.

FIG. 5. - Phagocytotic activity of a cell cultured under the same conditions as in figures 3 and 4. The arrows indicate the presence of cell debris $(\times 15000)$. 

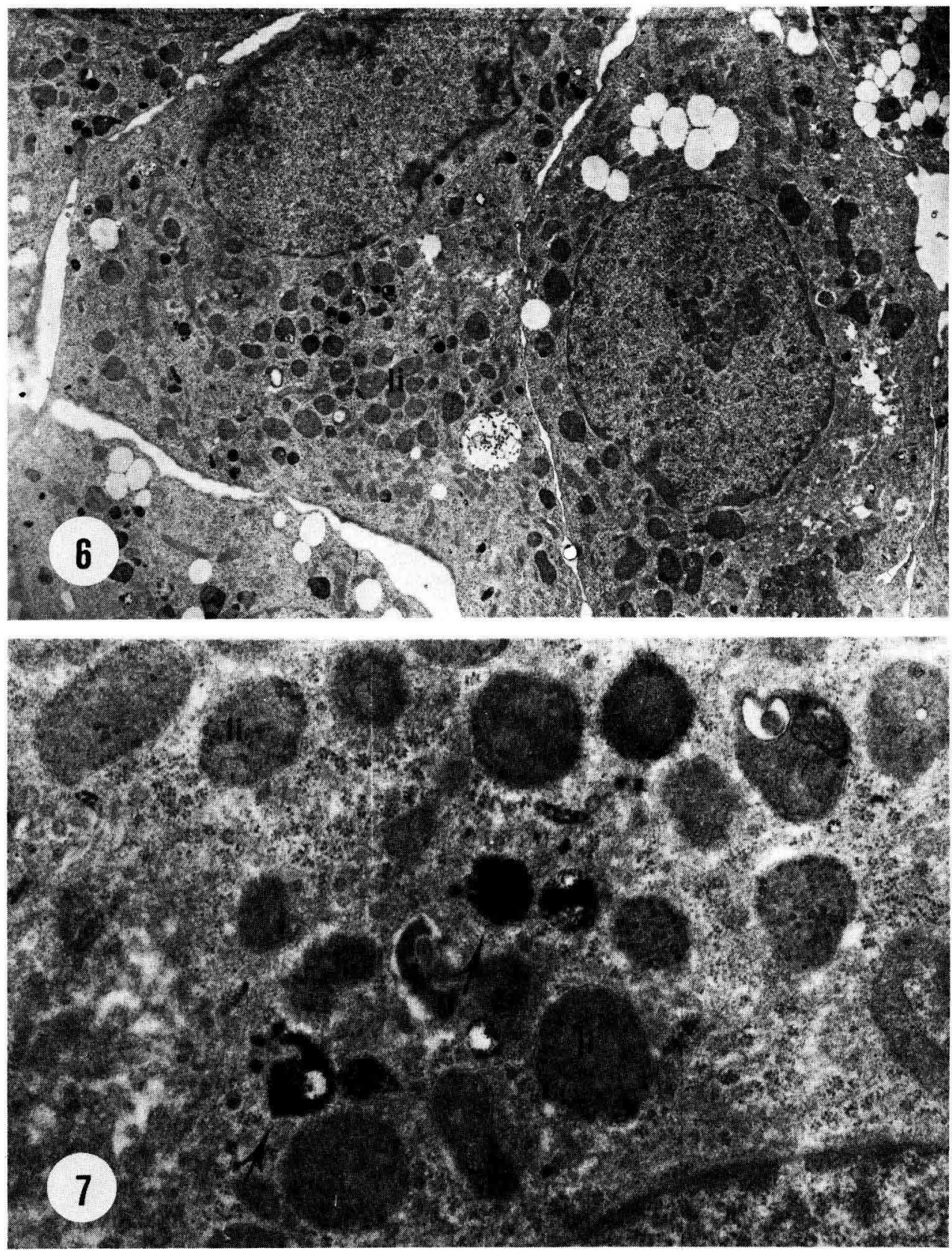

FIG. 6. - Cells incubated for 3 days in control medium 2. Numerous lysosome-like bodies (li) are randomly distributed in the cytoplasm $(\times 4400)$.

FIG. 7. - High magnification of part of the same cell as in figure 6. Channel-like formations and vesicles of different diameters containing peroxidase (arrows) are present as well as lysosome-like bodies (li) $(\times 22000)$. 


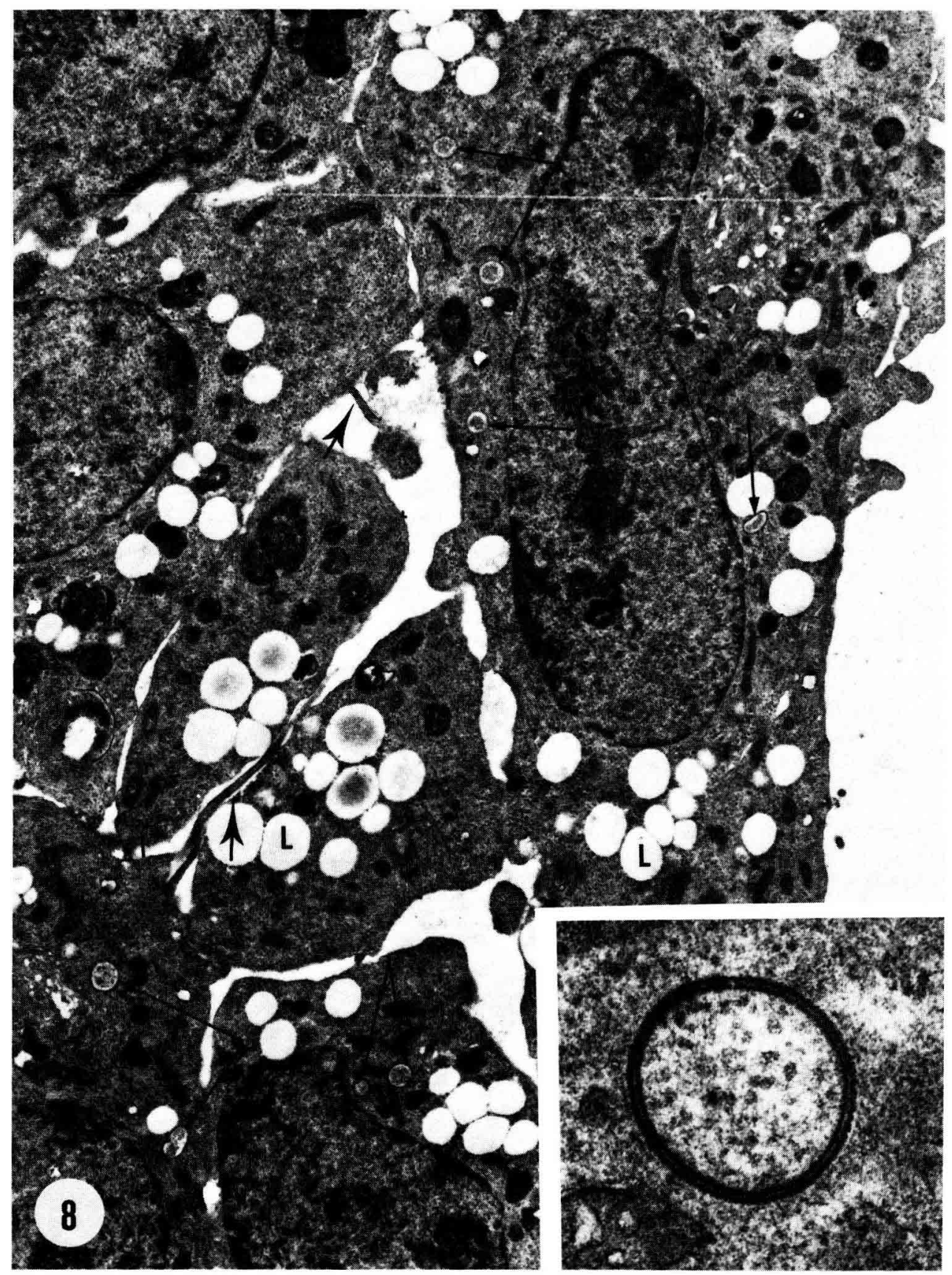

FIG. 8. - Low magnification micrograph of cell incubated for 1 day in medium 3 (total FF). Microvilli (large arrows), numerous lipid droplets (L), and cell-to-cell trilaminar junctions of the annular nexus type (small arrows) can be seen $(\times 6200)$. Inset shows higher magnification of a nexus $(\times 72000)$. 
After 3 days of incubation, the cells have a more regular outline. Many cell-to-cell trilaminar junctions are present, similar to what is found after 24 hrs of incubation. Numerous pleiomorphic mitochondria containing electron-dense matrices and predominantly lamelliform cristae are visible (fig. 3). The amount of microtubules and degree of retention of peroxidase have notably increased (fig. 4). Phagocytotic activity remains high and microvilli are scant (fig. 5).

When LH is added to the control medium (medium 2), the same pattern of morphological development occurs as described above. After 3 days of incubation, lysosome-like bodies are more numerous (fig. 6), and abundant free ribosomes as well as some cisternae of smooth endoplasmic reticulum are present. The uptake of peroxidase appears to be greater in the presence of $\mathrm{LH}$, and channel-like formations containing peroxidase are often found joining the peroxidase-positive vesicles (fig. 7). There is little evidence of phagocytotic activity.

Total follicular fluid medium 3. - The cell surfaces of granulosa cells incubated for 1 day in FF medium often display pseudopodia-like formations and/or microvilli (fig. 8), as well as a cell coat heavily stained with ruthenium red (fig. 9). Both granular and agranular endoplasmic reticulum cisternae are scarce. Lipid droplets and free ribosomes are abundant (fig. 9), and microtubules together with bundles of microfilaments are also present. Cell-to-cell trilaminar junctions of the annular nexus type are frequently found (fig. 8). The majority of the mitochondria are of the villiform type. Strongly peroxidase-positive lysosome-like bodies and multivesicular bodies are numerous in some cells (fig. 10), but phagocytosis is rarely observed.

After 3 days of incubation in medium 3, the granulosa cells are polygonal and their nuclei have a relatively homogeneous appearance of low electron density. A single prominent nucleolus is centrally located (fig. 11). The cell surface is poorly stained by ruthenium red and numerous microvilli are present. The cytoplasma contains abundant free ribosomes and small elements of granular endoplasmic reticulum (fig. 12). These cells possess large pleiomorphic mitochondria with tubular cristae and dense matrices, lysosomes, and a moderate to high number of lipid droplets (figs. 11, 12). Necrotic areas and/or membranous cellular debris are rarely observed.

Steroid-free follicular fluid medium 4. - In the presence of steroid-free FF, the granulosa cells develop ultrastructural features similar to those found after incubation in total FF. However, after 3 days, the mitochondria of cells incubated in the former medium have a varied aspect : some possess fubular cristae and contain one or several electron-dense granules; others exhibit lamelliform cristae; and still others

FIG. 9. - Cells incubated under the same conditions as in figure 8 . The surface coats are well stained by ruthenium red and there are abundant polyribosomes $(X 24000)$.

FIG. 10. - Part of a cell cultured as in figure 8 but without ruthenium red staining. Note the numerous peroxidase-positive lysosome-like bodies ( $\times 24000)$. 

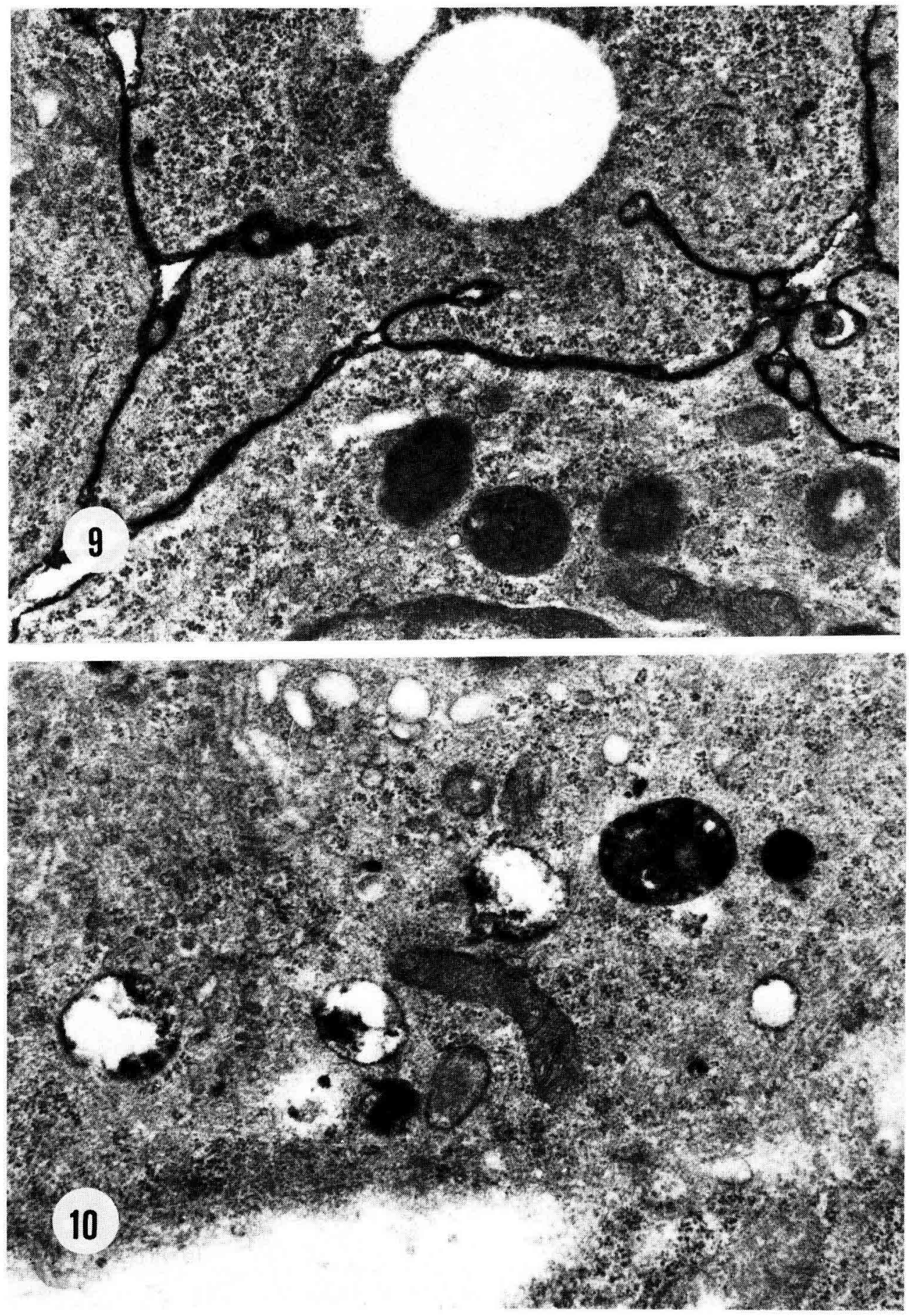
display both villiform and lamelliform cristae (fig. 13). Phagocytosis of cell debris is frequently observed. When this is present, those cells engaged in phagocytotic activity have mitochondria with lamelliform cristae (fig. 14).

\section{Discussion.}

It is conceivable that the high degree of autolysis and phagocytosis found in cells cultured in serum medium (see table 1) could retard some aspects of the luteal differentiation of rat granulosa cells in vitro, since these processes may be mutually exclusive. Thus, FF appears to be a better incubation medium for the survival of rat granulosa cells than serum medium.

Staining of the cell membrane by ruthenium red decreases during incubation in all media. It is interesting to note that the granulosa cells lose the ability to specifically biosynthesize mucopolysaccharides after a few days in culture, in contrast to what has been reported under in vivo conditions (Hartek, 1948 ; Lipner, 1974). Moreover, the amount of microtubules increases in all media with time, suggesting that both these ultrastructural changes may result from nonspecific responses to the in vitro conditions.

Total pig FF medium permits the complete differentiaticn of the mitochondria in rat granulosa cells in vitro, while steroid-free FF allows only limited mitochondrial differentiation, as evidenced by the persistence of many lamelliform cristae. However, complete luteal differentiation of the cell does not take place in either medium : there is a total absence of smooth endoplasmic reticulum. A similar dissociation of effects on mitochondria and other cellular organelles produced by hormones or inhibitory compounds like chloramphenicol, actinomycin D, puromycin and 5-bromodeoxyuridine have been demonstrated by Kahri (1973) and Kahri ef al. (1976). These investigators suggest that these inhibitors act only on mitochondrial DNA and do not affect nuclear DNA, which is stimulated by ACTH.

Bernard (1975) demonstrated that rat granulosa cells incubated in total pig FF medium secrete elevated levels of progesterone compared with cells incubated in control FCS or steroid-free pig FF media. Total FF was thought to be able to stimulate progesterone synthesis as a result of the presence of estrogen. In fact, estrogen may have a luteotrophic effect in some species in vivo (Keyes and Nalbandov, 1967 ; Greenwald, 1973 ; Takayama and Greenwald, 1973) as well as in vitro (Fuller and Hansel, 1971 ; Goldenberg et al., 1972 ; Bernard, 1975). However, recent results indicate that androgens also stimulate progesterone synthesis in cultured rat granulosa cells (Hillier et al., 1977 ; Lucky et al., 1977 ; Nimrod, 1977a) and bovine follicles (Shemesh and Ailenberg, 1977). Androstenedione was found to be effective at $1 \mu \mathrm{g} / \mathrm{ml}$, and testosterone at doses ranging from $30 \mathrm{pg} / \mathrm{ml}$ to $30 \mathrm{ng} / \mathrm{ml}$.

FIG. 11. - A prominent nucleolus (nu) and a nucleus with a homogeneous matrix are found after 3 days of incubation in medium 3. Large mitochondria, scattered lipid droplets (L), and a cell surface poorly stained by ruthenium red (arrows) are present $(\times 6400)$. Inset shows detail of a mitochondrion with tubular cristae $(\times 24000)$. 


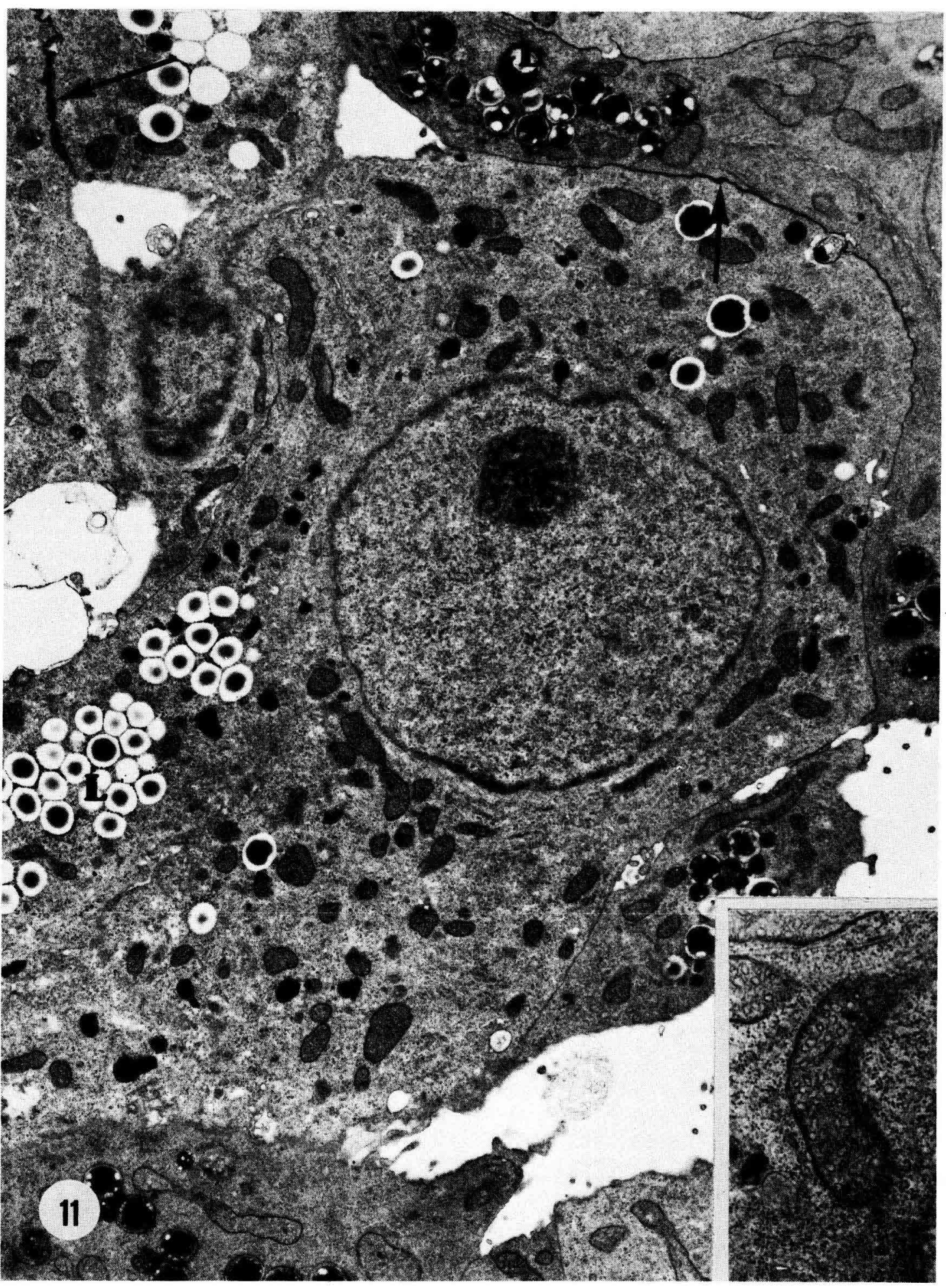



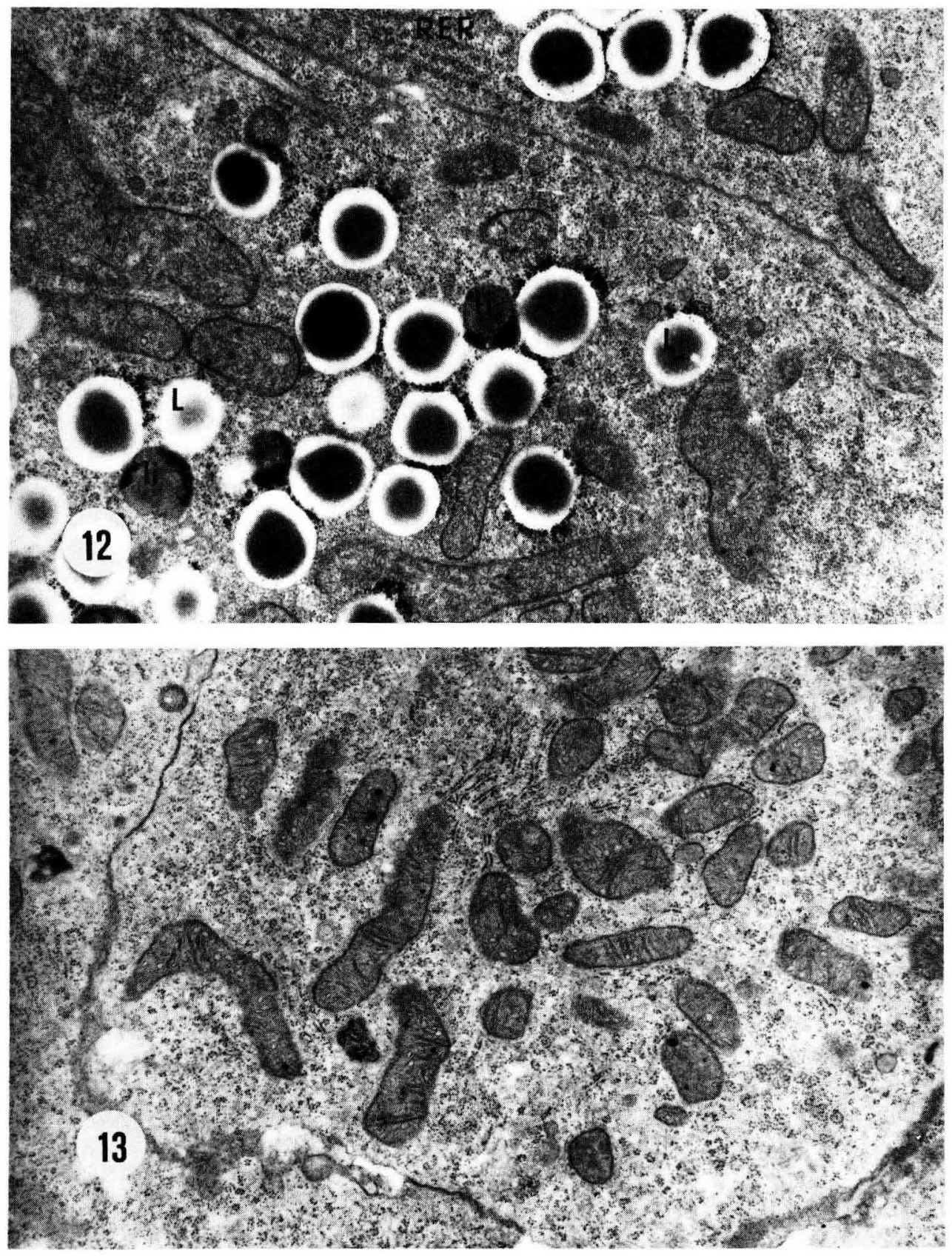

FIG. 12. - Part of the same sample as in figure 11, demonstrating the presence of differentioted tubular cristae within the mitochondrio. Many lipid droplets (L), 2 lysosome-like bodies (li), and some cisternae of rough endoplasmic reticulum (RER) are also evident $(\times 14000)$.

FIG. 13. - Part of a cell incubated for 3 days in medium 4 (steroid-free FF). Numerous mitochondria with both villiform and lamelliform cristae, rough endoplasmic reticulum, and free polyribosomes are present $(\times 9000)$. 


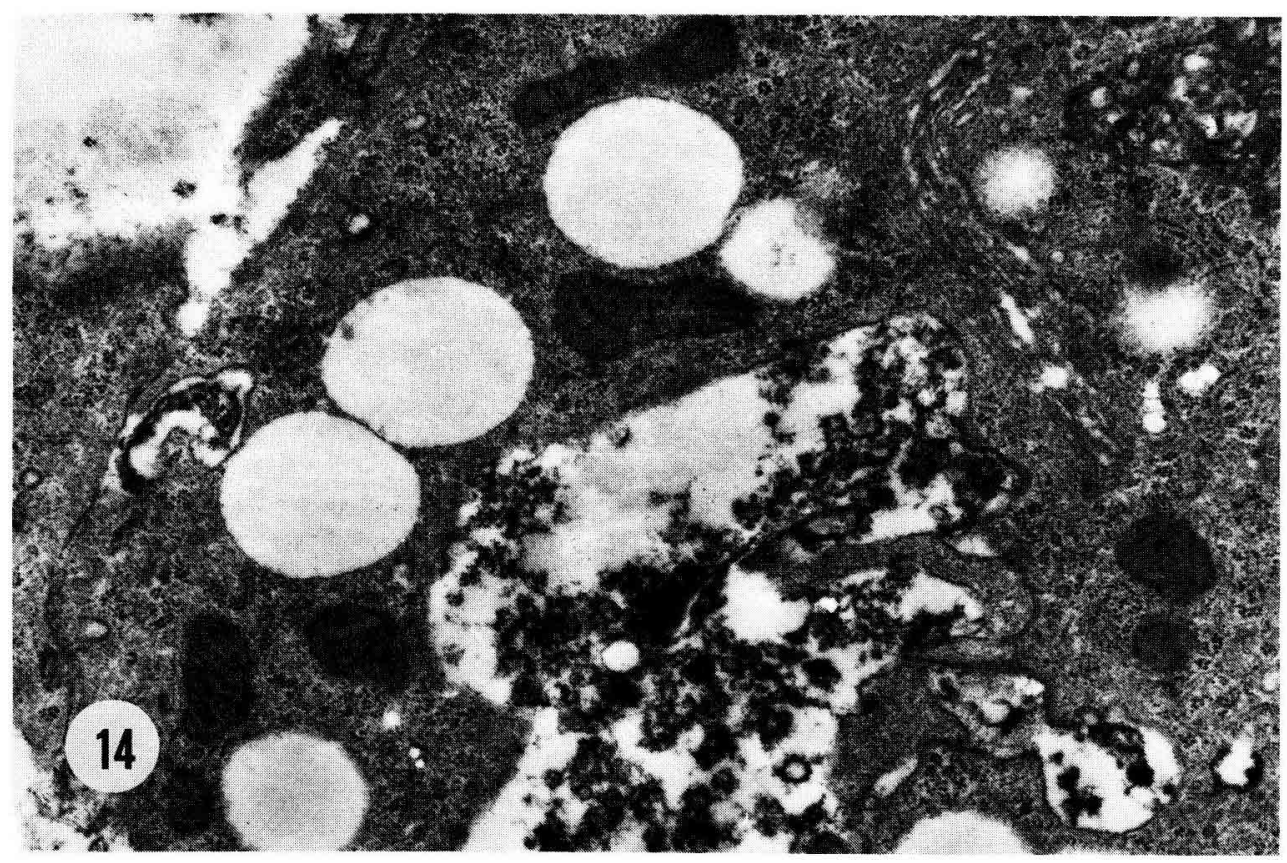

FIG. 14. - Cell cultured as in figure 13 showing phagocytotic octivity and mitochondria with lamelliform cristae $(\times 18000)$.

Previous data (Bernard, 1975 ; Robinson et al., 1975) and our own results suggest that progesterone biosynthesis in granulosa cells may be controlled in at least two different ways : LH may activate the enzymes required for the synthesis of pregnenolone ; or FF, estrogens or androgens may affect the next step - conversion of pregnenolone to progesterone - leading to complete differentiation of the mitochondria. These latter substances could act either directly by activating the mitochondrial enzymes or indirectly by enhancing cyclic AMP production (Nimrod, 1977b).

Our findings concerning the lack of effect of $\mathrm{LH}$ upon the ultrastructural differentiation of rat granulosa cells in vitro are in agreement with those of Crisp and Denys (1975). These authors conclude that $\mathrm{LH}$ alone is unable to induce complete morphological luteinization, and propose a sequential and synergistic action of both $\mathrm{LH}$ or hCG and prolactin or hPL on the control and maintenance of luteal function in the rat. Recently, Crisp (1977) has shown that prolactin alone $(1 \mu \mathrm{g} / \mathrm{ml})$ permits the complete differentiation of mitochondria in rat granulosa cells in vitro and that this process is associated with an increase in progesterone secretion ; control cultures lacking the added hormone show no such change. Unfortunately, the present study cannot be compared with these observations since it is not known if prolactin is present in pig FF.

It is interesting to note that pinocytosis, as measured by the ability of cells to incorporate peroxidase, appears to be inversely proportional to the degree of differentiation of the mitochondria. If verified, the different effects of total and steroid-free FF 
upon pinocytosis and the mitochondria would become especially intriguing, in view of their similar effects on the nucleus, membrane surfaces and microvilli (Bernard and Chrétien, 1978).

In conclusion, our data in conjunction with the findings previously published by Bernard (1975) indicate that the active secretion of progesterone, the main function of luteal cells, is directly related to mitochondrial differentiation. The ultrastructural differentlation of other organelles does not seem to be necessary for this process to take place.

Reçu en avril 1979.

Accepté en novembre 1979.

Acknowledgments. - This work was supported by grant 48.116.1.76 from PLAMIRH (Programa Latinoamericano de Investigación en Reproducción Humana). The authors wish to thank Mr. Julian Coello for his excellent technical assistance and Ms. Marcella Vogt for her careful editing of the manuscript.

Résumé. L'ultrastructure des cellules de la granulose du rat provenant des follicules préovulaires a été étudiée après incubation dans un milieu contrôle, contenant du sérum fétal de veau (FCS) avec ou sans LH $(1 \mu \mathrm{g} / \mathrm{ml})$, et dans un milieu contenant du liquide folliculaire de porc total ou dans le même milieu libre de stéroïdes. Tandis que les cellules cultivées dans ces différents milieux montrent une ultrastructure semblable après un jour d'incubation, on détecte des différences significatives après 3 jours. Dans le FCS, même avec $\mathrm{LH}$, l'autolyse et l'activité phagocytique restent élevées et les cellules ne développent aucun des caractères ultrastructuraux des cellules sécrétrices de stéroïdes. Au contraire, le milieu total FF provoque une différenciation complète des crêtes mitochondriales, changeant de crêtes lamelliformes à crêtes tubulaires. De milieu FF libre de stéroïdes produit la même gamme d'effets que le milieu total FF mais la différenciation mitochondriale n'est pas complète. Ces observations, adjointes aux études antérieures dans lesquelles on a mesuré la sécrétion de progestérone dans des cellules cultivées dans les milieux cités précédemment, suggèrent que l'accroissement de la capacité des cellules lutéales de rat de sécréter de la progestérone pourrait être directement liée à la différenciation mitochondriale.

\section{References}

BERNARD J., 1975. Effect of follicular fluid and oestradiol on the luteinization of rat granulosa cells in vitro. J. Reprod. Fertil., 43, 453-460.

BERNARD J., CHRÉTIEN F. C., 1978. Effect of follicular fluid on the surface ultrastructure of rat granulosa cells in vitro. Biol. Reprod., 19, 133-143.

CRISP T. M., 1977. Hormone requirements for early maintenance of rat granulosa cell cultures. Endocrinology, 101, 1286-1297.

CRISP T. M., DENYS F. R., 1975. The fine structure of rat granulosa cell cultures correlated with progestin secretion, 3-33. In HESS M., Electron microscopic concepts of secretion, John Wiley and Sons, New York.

EDWARDS R. G., 1974. Follicular fluid. J. Reprod. Fertil., 37, 189-229.

FULLER G. B., HANSEL, W., 1971. Estrogen-stimulated progesterone synthesis by rabbit corpora lutea in vitro. Proc. Soc. exp. Biol. Med., 137, 539-542.

GOLDENBERG R. L., BRIDSONW. E., KOHLER P. O., 1972. Estrogen induced progesterone synthesis in granulosa cells in culture, 172. In Proceed. 4th Congr. Endocrinol., Excerpla med., Amsterdam.

GRAHAM R. C., KARNOVSKY M. J., 1966. The early stages of absorption of injected horseradish peroxidase in the proximal tubules of mouse kidney : ultrastructural cytochemistry by a new technique. J. Histochem. Cytochem., 14, 291-302. 
GREENWALD G. S., 1973. Further evidence for a luteotropic complex in the hamster : progesterone determinations of plasma and corpora lutea. Endocrinology, 92, 235-242.

HARTEK B. T., 1948. Glycogen and carbohydrate-protein complexes in the ovary of the white rat during the oestrous cycle. Anat. Rec., 102, 349-367.

HILLIER S. G., KNAZEK R. A., ROSS G. T., 1977. Androgenic stimulation of progesterone production by granulosa cells from preantral ovarian follicles : further in vitro studies using replicate cell cultures. Endocrinology, 100, 1539-1549.

KAHRI A. I., 1973. Inhibition of ACTH-induced differentiation of cortical cells and their mitochondria by corticosterone in tissue culture of fetal adrenals. Anat. Rec., 176, 253-272.

KAHRI A. I., SALMENPERÄ M., SAURE A., 1976. Effects of 5-bromodeoxyuridine on the ACTHdependent mitochondrial biogenesis in cortical cells of fetal rat adrenals in tissue culture. J. Cell Biol., 71, 951-956.

KEYES P. L., NALBANDOV A. V., 1967. Maintenance and function of corpora lutea in rabbits depend on estrogen. Endocrinology, 80, 938-946.

LEDWITZ-RIGBY F., RIGBY B. W., GAY V. L., STETSON M., YOUNG J., CHANNING C. P., 1977. Inhibitory action of porcine follicular fluid upon granulosa cell luteinization in vitro : assay and influence of follicular maturation. J. Endocrinol., 74, 175-184.

LIPNER H., 1974. Mechanism of mammalian ovulation, 409-438. In GREEP R. O., ASTWOOD E. B., Handbook of Physiology, Sect. 7, Vol. II, Part. 1, Amer. physiol. Soc., Washington, D. C.

LUCKY A. W., SCHREIBER J. R., HILLIER S. G., SCHULMAN J. D., ROSS G. T., 1977. Progesterone production by cultured preantral rat granulosa cells : stimulation by androgens. Endocrinology, 100, 128-133.

NIMROD A., 1977a. Studies on synergistic effect of androgens on stimulation of progestin secretion by FSH in cultured rat granulosa cells. Progesterone metabolism and effect of androgens. Mol. Cell Endrocrinol., 8, 189-200.

NIMROD A., 1977b. Studies on synergistic effect of androgen on stimulation of progestin secretion by FSH in cultured rat granulosa cells. Search for mechanism of action. Mol. Cell Endocrinol., 8, 201-212.

ROBINSON J., STEVENSON P. M., BOYD G. S., ARMSTRONG D. T., 1975. Acute in vivo effects of hCG and LH on ovarian mitochondrial cholesterol utilization. Mol. Cell Endocrinol., 2, 149155.

SHEMESH M., AILENBERG M., 1977. The effect of androstenedione on progesterone accumulation in cultures of bovine ovarian follicles. Biol. Reprod., 17, 499-505.

TAKAYAMA M., GREENWALD G. S., 1973. Hormonal requirements for the maintenance of luteal function in hypophysectomized, pseudopregnant rats. J. Endocrinol., 56, 421-429.

VENABLE J. H., COGGESHALL R., 1965. A simplified lead citrate stain for use in electron microsCOpy. J. Cell Biol., 25, 407-408.

ZETTERQVIST H., 1956. The ultrastructural arganization of the columnar absorbing cells of the mouse jejunum. Thesis, Karolinska Inst., Stockholm. 